Journal of

Education and Practice (JEP)

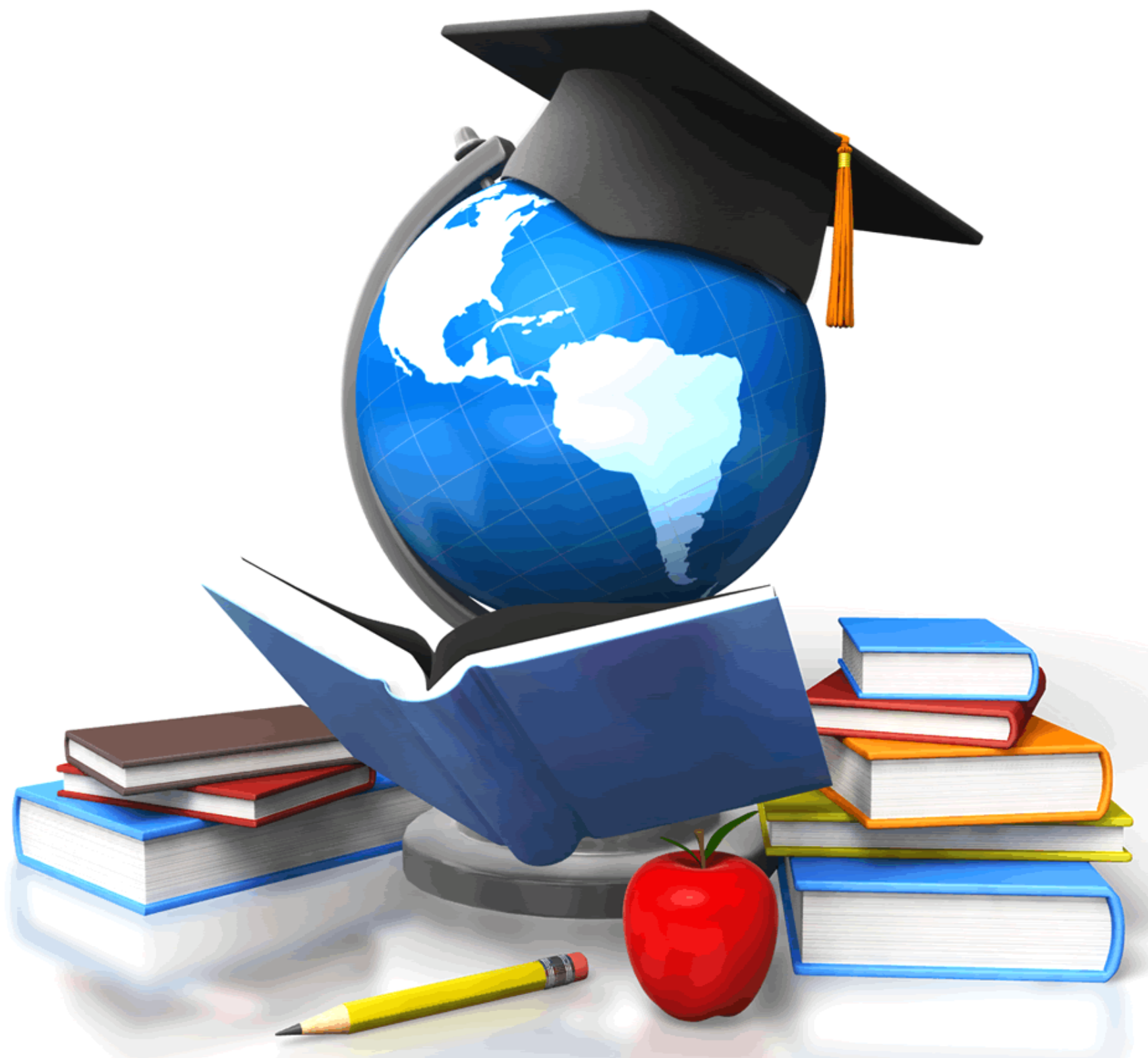

THE INFLUENCE OF CLASS LEVEL ON PARENTAL DEMANDINGNESS, MALE ADOLESCENT REBELLIOUS BEHAVIOUR AND ACADEMIC PERFORMANCE IN PUBLIC SECONDARY SCHOOLS Jane Macharia, Dr. Mulambula, M. Shikuku CARI 


\title{
THE INFLUENCE OF CLASS LEVEL ON PARENTAL DEMANDINGNESS, MALE ADOLESCENT REBELLIOUS BEHAVIOUR AND ACADEMIC PERFORMANCE IN PUBLIC SECONDARY SCHOOLS \\ ${ }^{1 *}$ Jane Macharia \\ ${ }^{1 *}$ Post graduate student, School of Education \\ Moi University \\ *Corresponding Author's Email: jane.macharia48@yahoo.com \\ ${ }^{2}$ Dr. Mulambula, M. Shikuku \\ Senior Lecturer, School of Education
}

\begin{abstract}
Purpose: The purpose of this study was to determine the influence of class level on PD, male adolescent rebellious behavior and academic performance in public secondary schools in Kiambu district.

Methodology: The study used ex-post facto research design. Stratified sampling was used to select the participants in the study. Schools were stratified into single sex and co-education schools. Systematic sampling using the class lists was used to identify the students who constituted the sample. The research instruments were the students' questionnaire, the deputy principal's and the teacher counsellor's interview guide. The sample constituted 240 male students, six deputy principles and six teacher counselors. A pilot study was done to pre-test the research instruments so as to estimate their reliability and validity. Data collected was analyzed using Statistical Package for Social Sciences (SPSS). The findings were presented using descriptive and inferential statistics. Descriptive statistics included, frequency distribution, means, bar graphs, and tabulated according to the research objectives. Inferential statistics used included Chi Square and pearson correlation to test the hypotheses at $90 \%$ and 95\% level of confidence; correlation coefficient was used to measure the strength of linear relationship between the variables of the study.

Results: Class level was found to have no significant relationship with PD and rebellion but it had a significant relationship with academic performance.

Unique contribution to theory, practice and policy: The study came up with a model that is recommended to schools for adoption by guidance and counselling teachers to help create awareness and understanding to both the students and parents with the aim of improving or bettering their relationship, academic performance and prevent rebellion in public secondary schools.
\end{abstract}

Keywords: parental demandingness, male adolescent, rebellious behaviour, class level, public secondary schools 
Journal of Education and Practice

ISSN 2520-467X (Online)

Vol.1, Issue 1 No.1, pp 19-34, 2016

www.carijournals.org

\subsection{INTRODUCTION}

Adolescence is the period between childhood and adulthood (Njenga, 2010; Lester, 1993). It is the transition period lasting from the onset of puberty to the beginning of adulthood. Adolescence marks the period of physical, psychological and social development. The stage is characterized by rapid physical changes, transforming a child into an adult with significant new cognitive ability, emotional maturation, sexual awakening and a heightened sensitivity to peer relations (Njenga, 2010, Philip and Barbara, 1986).

Boys' physical maturation poses different challenges to them. Physical increase in height and muscles may bring well developed physical skills that are highly valued by peers and adults as well thus increasing the boy's self esteem. However, this may leave a boy feeling awkward and uncoordinated for a time. The boy might not accomplish what he might expect. Psychologically the period poses some challenges to the boy's self esteem. The maturation process used to take a little longer a century ago (Lester, 1993) unlike in the contemporary world (Carole and Karen, 1997; Nancy, 2001). Full engagement in the adult society requires more training, education and complex preparation. Adolescence is therefore prolonged with more time to experience with drugs, and sexual experimentations. Physical changes produce ambivalence. Early maturers are more popular and achieve recognition thus becoming more self confident and less dependent. Late maturers are more rebellious and more concerned with rejection (Nancy, 2001). If the family is not supportive negative feelings are likely to result.

Adolescence cognitive development is less dramatic than physical development. There is no obvious surge in mental development to match the surge in physical development. According to Piaget and Inhelder (1956), a qualitative shift in thinking occurs from concrete to formal operational thought. This is governed more by logical principles than by perceptions and experiences. The adolescence use operations to manipulate and modify thoughts and other mental operations. They use reasoning about abstract and concrete situations. They are able to consider all the possible combinations of propositions and their interrelations. The adolescent is able to raise hypothesis to explain an event, and then follow the logic that a particular hypothesis implies. He/she is able to detect the logical consistency or inconsistency in a set of statements. They can test the truth of a statement by finding evidence that supports or disapproves the statement.

The adolescents are able to think in a relativistic way about themselves, other individuals and their world. They know they are expected to act in a particular manner because of the norms of their community and culture. Their quality of thought reflects what is possible rather than what is typical. The changes in conceptual development result in a more flexible, critical and abstract view of the world.

Adolescence is characterized by egocentrism. As children grow into adolescents, they develop the capacity to formulate hypothetical systems (Piaget and Inhelder, 1956). They begin to generate assumptions about their own and others behaviors that will fit into these abstract formulations (Nancy, 2001; Narina, Debra, and Warren, 2007). For example, an adolescent boy may insist that cooperation is more desirable mode of interaction than competition. Cooperation benefits each participant in a game and provides more resources in a group. He may become angry or disillusioned to discover that parents seek competitive 
Journal of Education and Practice

ISSN 2520-467X (Online)

Vol.1, Issue 1 No.1, pp 19-34, 2016

www.carijournals.org

experiences and appear to enjoy them. This kind of egocentrism reflects an inability to recognize that others may not share one's own hypothetical system.

Adolescents are aware of a more differentiated set of emotions. Among the more negative of these emotions are anxiety, shame, embarrassment, guilt, shyness, depressions and anger. Boys unlike girls have heightened awareness of increased negative emotions that focus on others such as, contempt and aggression (Njenga, 2010, Stapley and Haviland, 1989). Many of the adolescent problems may be linked to the expression, control and over control of emotions, for example, impulsive and high reactive to emotional arousing stimulus results to delinquent behaviors such as murder, arson, bullying (Robertson and Simons, 1989). Adolescence is a time of life when one is likely to encounter loss, failure and rejection, excessive demands, academic challenges, among others. How well the support is granted may assist in achieving a balance.

Erikson (1963) in his study of psychological stages noted that, at adolescence the task is the formation of identity. During this stage the primary conflict of adolescents is the identity crisis. Adolescents have to actively seek self definition and role or identity confusion results when they fail to develop a consistent definition. The adolescent develops a sense of identity by adopting his or her own set of values and social behaviors, but this generally does not occur before the adolescent experiment with a variety of values and social behaviors-often to the displeasure of parents. Marcia (1966) identified four identity statuses: foreclosure, moratorium, diffusion and achievement. In identity foreclosure, the adolescent prematurely adopts the values and behaviors mandated by his or her parents. This may lead to inauthentic personality and other personality disorders. In identity moratorium the adolescent postpones settling on a particular identity. This might be akin to Erikson's failure to find a satisfactory identity. In identity diffusion, the adolescent fails to make progress toward a sense of identity, arbitrary shifting from one to another and finally in identity achievement, the adolescent settles on a particular identity after trying several alternatives.

Defining who an adolescent is, gives him self esteem and a positive self concept. Self concept of adolescent is more complicated. The adolescents have more different views of themselves unlike young children. Their self perceptions include more categories of evaluation. Harter (1999) noted that increased differentiation is prompted by cognitive development along with social pressures to act differently in different situations. At age 15, they become distressed by their different selves and sometimes may act out in outrageous ways. It is therefore noteworthy that adolescents can be very argumentative and a- know it all attitude. They love to point out what other people including parents don't know. They have unrestrained idealism. They believe they can do better than their parents.

\subsection{Problem Statement}

The youth presents the world with an opportunity to accelerate growth and development and reduce poverty. This opportunity lies in the efficacy of education (World Bank, 2002). Education enables access to financial stability and financial base thus free people from bondage and sets them free to develop themselves. It is also a crucial predictor of several health related lifestyles and life expectancy.

When releasing the 2009 Kenya Certificate of Secondary Education results, the Minister of Education then remarked that the national ratio for boys to girls stood at $54 \%$ and $46 \%$ respectively, except in central province. In the latter the percentage of girls was higher than that of boys at $51 \%$ to $49 \%$ respectively. The information from the District Education Office 
Journal of Education and Practice

ISSN 2520-467X (Online)

Vol.1, Issue 1 No.1, pp 19-34, 2016

www.carijournals.org

Kiambu noted this disparity too. The results for the national examinations between the years 2004-2012 were not good in Kenya Certificate of Secondary Education (KCSE) see table 1.

Table1: District KCSE results for 2004-2012

\begin{tabular}{|l|l|l|l|l|l|l|l|l|l|}
\hline Year & 2004 & 2005 & 2006 & 2007 & 2008 & 2009 & 2010 & 2011 & 2012 \\
\hline $\begin{array}{l}\text { Mean } \\
\text { Score }\end{array}$ & 4.367 & 4.8121 & 4.981 & 4.8466 & 4.672 & 5.077 & 5.034 & 5.196 & 5.230 \\
\hline
\end{tabular}

Source: District education office

Data from District Education Office (2011) for district secondary school enrolment for boys has been outnumbered by that of girls (4,792 boys and 5,535 girls)

Observations by Biu, (2011); Kinai, (2002); Musuikuya, (2006); Onyasimi, (2006); Onancha, (2007); and Ngwiri, (2008) show that boys in secondary schools have been involved in rebellious behaviors such as, drug abuse and school strikes among others. Kiambu District has the highest number of children involved in vices such as drug trafficking, taking of marijuana and production of illicit brews. In Central Kenya the situation has been made worse by recruitment into unlawful Mungiki sect (Wangui, 2008). The recruited boys molest others in school and outside school as day scholars go home. (Ngare, 2000). They get involved in activities such as extortion, touting, taking and trafficking drugs, and truancy. Those who resist recruitment or payment of "protection fees" are harassed and their property within and outside school targeted with a series of destructive methods such as burning and killing to force them to comply. This creates a lot of fear.

The government has put up Guidance and Counseling Departments in secondary schools to help in counseling and giving advice to students with a view to preventing these maladaptive behaviors. It has also motivated teachers to go for professional counseling by giving them study leaves with pay (TSC Circular No 27/2011 see appendix 5).Schools have engaged their teachers and outsiders to give motivation talks to students.

Despite these measures, there have been increased acts of rebellion in the institutions of learning as noted by Biu (2011) and from District Quality Assurance Office, 2008 and 2012. These behaviors have the potential to curtail possibilities of meaningful academic achievement (Wesang'ula, John and Eric, 2011). Related to educational attainment is the parental relationship with the child. According to Njenga (2010), Ngwiri (2008), Dennis, (2004), the heart of child management is the relationship between parents and their children. The question that seems bothering is whether there is an influence of parental demandingness on male adolescent rebellion and academic performance in public secondary schools in Kiambu District? When parents fail to give a good start in life, everybody may end up suffering- the child, the parents, and the society as a whole (Dennis, 2004). The study investigated this influence and hopes to come up with empirical evidence which will help to create awareness on influence of parental demandingness on male adolescent rebellion and academic performance with a view to improving this relationship for better grades and healthy living.

\subsection{Research Objective}

To investigate the influence of class level on PD, male adolescent rebellious behavior and academic performance in public secondary schools 
Journal of Education and Practice

ISSN 2520-467X (Online)

Vol.1, Issue 1 No.1, pp 19-34, 2016

www.carijournals.org

\subsection{LITERATURE REVIEW}

\subsection{Empirical Review}

A study carried out by Xiaoming, Rong, Bonita and Qun (2009) among middle students in Nanjing on smoking experimentation and current smoking (past 30 days) showed that advanced age, male gender, low school performance and low educational aspirations were associated with smoking experimentation and current smoking. Depressive symptoms, social alienation, low self esteem, low social and academic monitoring, problem behavior, low parental responsiveness, parental smoking and its approval were positively associated with current smoking among Chinese adolescents.

Wang, Dishion Stormhark and Willett (2011) researched on reciprocal relations between family management practices and early adolescent problem behaviors during the middle school years in Pacific Northwest, America. Results indicated that as students' antisocial behavior and substance use increased, their positive behavior engagement decreased over time. Also as adolescent age increased, the parental knowledge of the adolescent's activities decreased as did parental rule making and support.

Steinberg and Silk (2002) asserts that as adolescents get older, their level of parental control decreases. Persons between the ages of 18 and 25 years are in ambiguous period where they have levels of autonomy comparable to adults; however, they do not have similar levels of responsibility (Arnett, 2002). Low levels of adult responsibility combined with more autonomy increase the chances of criminal behavior during this period.

Ruth (2009) investigated the effects of age and gender on parental control and delinquency in America. She administered delinquent acts and status substance abuse acts indexes to 402 white females and 402 white male adolescents aged 11-18 years. Results showed that there were significance differences by gender and age in the effect of parental controls on delinquency and by gender or age in relationship between parental controls and delinquency. Also parental controls were significant inhibitors of delinquency more often for males than females. For male, controls were more effective in mid- adolescence and for females in late adolescence. Attachment varied with age and parental control decreased as adolescent became older.

A longitudinal study was carried out by Gottfried, Fleming and Gottfried (2001) on two aspects of continuity, stability of individual differences and means from the middle elementary through the high school years among American adolescent. The results revealed that, with advancement in age, academic intrinsic motivation becomes increasingly stable but the mean level of academic intrinsic motivation declines over the ages.

In another survey in United Kingdom (UK), results showed that seventy per cent of 13-14 year olds and eighty nine per cent of 15-16 year olds had an alcoholic drink. The most common age for a first drink was twelve to thirteen years old usually when with an adult and celebrating a special occasion (Bremner, Burnet, Nunney and Mistal, 2011). Early adolescent alcohol use has been associated with delinquency and violence (Peleg-Oren, Saint-Jean, Gardens, Tammara, Pierre, (2009) and poor academic performance. The family is the key influence on children's and young people's behavior, (Sodhi and Turner, 2011) however; the family may have weak effects when interventions to reduce adolescent behavior are considered. As young people grow older the primary influences tend to move from the parents to peers. The parents increasingly lose their control as the adolescents progressively 
Journal of Education and Practice

ISSN 2520-467X (Online)

Vol.1, Issue 1 No.1, pp 19-34, 2016

www.carijournals.org

mature (Latendresse, Rose, Viken, Pukkinen, Kaprio and Dick, (2008). This survey renders the current study important because these are the ages which are in secondary schools in Kenya and it would be necessary to find out at whether age and class level influence parental demandingness.

The above studies show that apart from parental control affecting the adolescent's behavior and academic performance, the adolescent's age and plus the family does affect the parent's control. As age advances, parent's control decreases (Latendresse et al, 2008). This renders this study relevant because it will empirically prove whether the said claims are applicable to male adolescent's students in public secondary schools in Kiambu District hence provide vital data missing in this area for purposes of helping parents understand the interative effects thus create conducive environment for healthy co-existence.

These studies seem to point to the importance of age and parental monitoring or control as important ingredients in decreasing or increasing adolescent rebellion. However as per whether class level and age influence Parental demandingness is left out hence this becomes a matter of concern for the current research.

Family types refer to divorced or separated, single parent, remarried and conflicted families. Living in household where divorce is taking place, adolescents will likely be exposed to their parents' hostility and recriminations before and during divorce. This exposure is often painful and damaging to them (Ngwiri and Tumuti, 2010; Kelly, 2000).

Divorce is highly stressful and painful to most adults experiencing it. It affects many aspects of their lives including how they implement their demands on children. The mother has to take up all the parenting roles that were previously carried out by the father and she also has increased employment responsibilities. The first year may see the mother less affectionate, lax in control and less consistent in her parenting. She may have difficulties imposing her control. She may become indulgent or indifferent. Disciplining children becomes difficult partially because children may blame their mothers for their fathers absence. She may also feel guilty about divorce and in an effort to win their favor she may not be strict to them. The adolescents in turn may have greater freedom than those in intact families. This freedom may be more than they can handle. Divorced fathers are resented and blamed by adolescents following years of divorce. This may affect their relationship with others (Kelly, 2000, Kinai, 2002, Lester, 1993)

Adolescents in remarried families may be depressed, anxious and may have conduct disorders. Sometimes they may reject or resist the authority of the new father or mother figure or become jealous and angry with a remarried mother. Boys in dual-earning and single parent families may not be supervised by parents due to lack of time hence they tend to have higher rates of social isolation and depression, (Jeffrey, 2004).

Parents in non-divorced families conflict too and this has equally serious conflicts on adolescents. Adolescents from such families witness their parents fight one another. They undergo martyr like long suffering hence they externalize or internalize anger. They have sadness, depression, low self esteem, poor problem solving skills, low academic performance and tend to be very aggressive with peers as a way of solving problems. They also have heightened suicidal risks (Ngwiri, 2008; Ngwiri and Tumuti, 2010). Parents in such households may not implement their demands.

A study carried out by Sharon and Cheryl (2010) on association between interparental conflict and academic achievement among 2,297 sixth grade European American youth 
Journal of Education and Practice

ISSN 2520-467X (Online)

Vol.1, Issue 1 No.1, pp 19-34, 2016

www.carijournals.org

demonstrated that, interparental conflict is a risk factor for lower academic achievement. The study concluded that family interactions play a significant role in how youth perform in the academic setting.

Osborne and McLanahan (2007) carried out a study on partnership instability and child wellbeing at Texas in Austin USA. Data from three waves of fragile families $(\mathrm{N}=2,111)$ study was used to examine the prevalence and effects of mother's relationship changes between birth and age 3 on their children's wellbeing. Results reveal that, children born to single mothers show higher levels of aggression behavior than children born to married mothers. George, Michael and Grace (1996) examined the impact of single- mother families and nonresident fathers on delinquency, heavy drinking and illicit drug use in black and white American adolescents. The study used 600 adolescent and their parents as a sample. From the results, white adolescent males with non- resident father involvement buffers the negative effects of single mother families on delinquency, heavy drinking and illicit drug use. The highest rates of problem behavior are found among white male adolescents in single mother families without support of a non-resident father. For black male adolescents, fewer problem behaviors were identified when non-resident fathers are not involved in single mother families.

Another study by Astone and McLanahan (1991) found that children from dysfunctional families and particularly those from single parent families, those with step parents and those affected by marital disruptions reported less monitoring of their school work and less supervision of their social activities as opposed to functional families without marital disruptions. This may leave them with a lot of time to experiment on mal adaptive behaviors.

In Kenya, John, Gerald, Odhiambo and Mary (2012) carried a study on factors influencing youth crime and juvenile delinquency. The study was done in Kamiti Youth Corrective Training Centre the only penal institution for young male offenders aged 17-21 years in Kenya. It involved 55 inmates, randomly selected from 120 inmates. Out of 55, it was found that 31respondents aged 17 years while 24 aged between 18-21 years. Data was collected through questionnaire and interviews. Researchers highlighted the cause of crimes as poverty, drugs and rebellion against parental authority, broken homes and low educational attainment. Most of the youth were from dysfunctional families; single parents, divorced, conflicted, and alcoholic parents, who could not offer good parenthood. Among the 55 sampled youth, 7 had parents who had separated, 6 with no mothers, 14 were fatherless and 8 had no parents at all. Studies by Kinyua (2007) and Munyua (2007) on the influence of pupils' perception of parenting styles on their academic performance in primary and secondary schools respectively in Eldoret municipality Kenya showed that pupil's perception significantly influence their academic performance. Also there was a strong association between pupil's perception of parenting style and family size but class level did not significantly influence pupil's perception of parenting styles. The type of family and gender had no significant influence on students' perception.

The above literature review showed that age, unconventional families (where either father or mother is absent), conflicted and unstable parental relationships contributes to how the parents in trying to implement their demands on the adolescent may lead to adolescents' antisocial behaviors such as smoking, delinquency and other crimes. Most of the said studies were either done in a special training school where most youths were already convicted criminals or measured other variables different from the one focused in the current study. 
Journal of Education and Practice

ISSN 2520-467X (Online)

Vol.1, Issue 1 No.1, pp 19-34, 2016

www.carijournals.org

None of the studies was done among male adolescent students at all levels form one to form four and specifically in Kiambu district. The current study will focus on age, the class level of male adolescent students and the family and not the size, in order to find out their influence on the parental demandingness.

Survey of the available research also shows that adolescent experience psychological difficulties once their parents' marital status change to the negative. However, very limited studies seem to have focused on the perception of male adolescent of their family status influence on their rebellion and academic performance, hence the concern of this research.

\subsection{RESEARCH METHODOLOGY}

In this study, mixed research method was applied thus both quantitative and qualitative research methods was used. The quantitative method involved collection and analysis of numerical data whereas qualitative method involved collection and analysis of narrative data from interviews. Quantitative approach was used to analyze the collected data from students through questionnaires while qualitative method was used to analyze data collected from teacher counselors and deputy principals through interviews. The study employed ex-post facto research design to collect information on male students' perception on the influence of their parental demandingness on their rebellion and academic performance in Kiambu district. This research design explored the relationship between variables. The target population of the study was all male students 4,792 from the sixteen public secondary schools as per 2011 enrolment 16 deputy principals and 16 teacher counselors from the three zones namely Ndumberi, Kihara, and Karuri.

The population was also distributed according to school type as mixed or co-education day schools and single sex boarding schools. In this study the population was 4,792 and the sample size was 240 students. The data for this study was generated using questionnaires and interview.

Quantitative data was collected through questionnaires. It was prepared in readiness for analysis by editing, coding, categorizing and keying into Statistical Package for Social Sciences (SPSS) computer software for analysis. SPSS was used to produce frequencies, descriptive and inferential statistics which was used to derive conclusions and generalizations regarding the population. Qualitative data was analyzed using narratives. Quantitative data was analyzed using inferential statistics such as Pearson Product moment correlation coefficient and chi square to test the hypotheses at $95 \%$ levels of confidence respectively and find the significance of correlation levels.

\subsection{RESULTS AND DISCUSSIONS}

\subsection{Response Rate}

The number of questionnaires, administered to all the respondents, was 240. A total of 236 questionnaires were properly filled and returned from the students. This represented an overall successful response rate of 98\%. According to Mugenda and Mugenda (2003), a response rate of $50 \%$ or more is adequate. Babbie (2004) also asserted that return rates of $50 \%$ are acceptable to analyze and publish, $60 \%$ is good and $70 \%$ is very good. 
Table 2: Response Rate

\begin{tabular}{lcc}
\hline Response & Total & Percent \\
\hline Returned & 236 & $98 \%$ \\
Unreturned & 4 & $2 \%$ \\
Total & 240 & $100 \%$ \\
\hline
\end{tabular}

\subsection{Demographic Characteristics}

\subsubsection{Class Level}

The respondents were asked to indicate which class they were in. Results in Figure 1 illustrate that $26.7 \%$ of the respondents were in form two, $25.8 \%$ of the respondents were in form four, $24.3 \%$ of the respondents were in form one while $23.3 \%$ of the respondents were in form three The findings imply that most of the respondents were in form two and this is in line with study expectations since the number of form two students is expected to be higher compared to other classes as a result of school policy of repetition and also allowing form three students from other schools to repeat in form two.

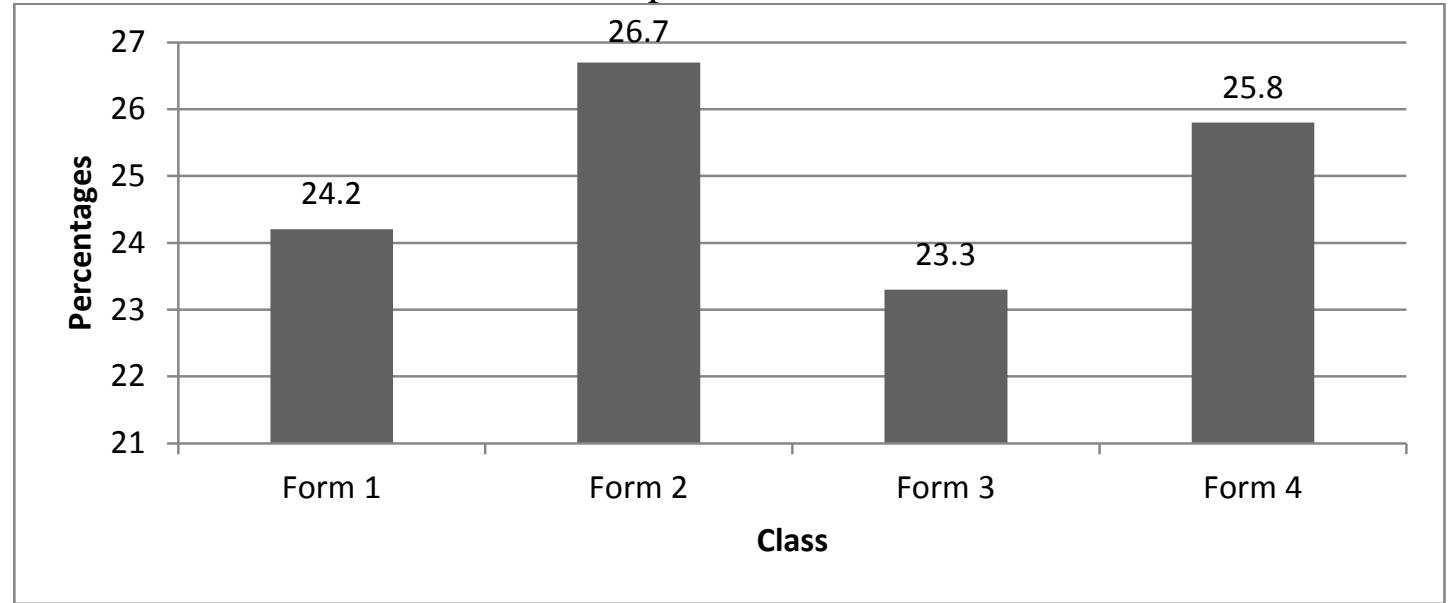

Figure 1: Class Level

\subsection{Inferential Statistics}

\subsubsection{Class Level and Adolescent Rebellion}

A cross tabulation of class level and adolescent rebellion in table 3 indicates that there is no significant relationship between class level and adolescent rebellion. This is supported by a chi-square of 2.714(0.844). Since a p-value of 0.844 is greater than the conventionally accepted significance level of 0.05 (i.e. $p>0.05$ ) the null hypothesis was accepted. In other words, there is no statistically significant relationship between class level and adolescent. The contingency coefficient for the association was 0.11 .

Table 3: Cross-tab of class level and adolescent rebellion

\begin{tabular}{llccccc}
\hline & Adolescent Rebellion & Low & ambivalent & high & Total & Chi square \\
\hline Class & Form 1 & 54 & 1 & 1 & 56 & \\
& Form 2 & 61 & 1 & 1 & 63 & \\
& Form 3 & 51 & 2 & 0 & 53 & $2.714(0.844)$ \\
& Form 4 & 58 & 2 & 0 & 60 & \\
Total & 224 & 6 & 2 & 232 & C $=0.11$ \\
\hline
\end{tabular}




\subsubsection{Class Level and Parental Demandingness}

A cross tabulation of class level and parental demandingness in table 4 indicates that there is no significant relationship between class level and parental demandingness. This is supported by a chi-square of $12.064(\mathrm{p}=0.061)$. Since a $\mathrm{p}$-value of 0.061 is greater than the conventionally accepted significance level of 0.05 (i.e. $p>0.05$ ), the null hypothesis is accepted. In other words, there is no statistically significant relationship between class level and parental demandingness. The contingency coeffiecient for the association was 0.23. However, the level of demandingness was lowest in form four.

Table 4: Cross-tab of class-tab of class level and PD

\begin{tabular}{llccccl}
\hline & PD & Low & Ambivalent & High & Total & Chi square \\
\hline Class & Form 1 & 3 & 38 & 13 & 54 & \\
& Form 2 & 13 & 35 & 13 & 61 & \\
& Form 3 & 10 & 26 & 14 & 50 & \\
& Form 4 & 16 & 33 & 8 & 57 & $12.064(\mathrm{p}=0.061)$ \\
& Total & 42 & 132 & 48 & 222 & $\mathrm{C}=0.23$ \\
\hline
\end{tabular}

\subsubsection{Class Level and Academic Performance}

A cross tabulation of class level and academic performance in table 5 (a) indicates that there is significant relationship between class level and academic performance. This is supported by a chi-square of $26.561(\mathrm{p}=0.000)$. Since a $\mathrm{p}$-value of 0.000 is less than the conventionally accepted significance level of 0.05 (i.e. $\mathrm{p}<0.05$ ), the null hypotheses was rejected. In other words, there is statistically significant relationship between class level and academic performance. The contingency coefficient for the association was 0.32 .

Table 5 (a): Cross-tab of class level and academic performance

\begin{tabular}{llccccl}
\hline & $\begin{array}{c}\text { Academic } \\
\text { performance }\end{array}$ & $\begin{array}{c}\text { low } \\
\text { performan } \\
\text { ce }\end{array}$ & $\begin{array}{c}\text { Average } \\
\text { performance }\end{array}$ & $\begin{array}{c}\text { high } \\
\text { performanc } \\
\text { e }\end{array}$ & $\begin{array}{c}\text { Tot } \\
\text { al }\end{array}$ & Chi square \\
\hline Cla & & 8 & 25 & 24 & 57 & \\
Ss & Form 1 & 24 & 33 & 6 & 63 & \\
& Form 2 & 21 & 23 & 11 & 55 & $26.561(\mathrm{p}=$ \\
& Form 3 & 17 & 35 & 9 & 61 & $0.000)$ \\
& Form 4 & 70 & 116 & 50 & 236 & C=0.32 \\
& Total & 70 & & & & \\
\hline
\end{tabular}

ANOVA results presented in table 5(b) revealed that there is a significant relationship between class and academic performance. The highest mean score was obtained in form 1 and this is in line with study expectations which are that the curriculum content for form 1 is less tasking and concentrated compared to content for other classes. This finding is supported by an $\mathrm{f}$ statistic of 10.077(which is larger than the f critical at degree of freedom of 3 and degree of freedom of 232). The associated $p$ value is less than the critical $p$ value of 0.05 and hence a significant relationship between class and academic performance exists. 
Table 5(b): ANOVA of class level on academic performance

\begin{tabular}{lcccc}
\hline Academic Performance & N & Mean & Std. Deviation & f stat , p value \\
\hline Form 1 & 57 & 50.23 & 15.936 & \\
Form 2 & 63 & 36.56 & 15.058 & \\
Form 3 & 55 & 38.05 & 16.265 & $10.077(\mathrm{p}=0.000)$ \\
Form 4 & 61 & 38.33 & 13.562 & \\
Total & 236 & 40.67 & 16.056 & \\
\hline
\end{tabular}

Post hoc results in table 5(c) revealed that significant differences in performance existed between form 1 and form 2, between form 1 and form 3, and between form 1 and form 4 . The rest of the intergroup differences were not significant.

Table 5(c): Post hoc test of class level on academic performance

\begin{tabular}{llccc}
\hline (I) Class & (J) Class & Mean Difference (I-J) & Std. Error & Sig. \\
\hline \multirow{3}{*}{ Form 1 } & & & & \\
& Form 2 & $13.673^{*}$ & 2.779 & 0.00 \\
& Form 3 & $12.174^{*}$ & 2.873 & 0.00 \\
Form 2 & Form 4 & $11.900^{*}$ & 2.8 & 0.00 \\
& Form 1 & $-13.673^{*}$ & 2.779 & 0.00 \\
& Form 3 & -1.499 & 2.805 & 0.59 \\
Form 3 & Form 4 & -1.772 & 2.73 & 0.52 \\
& Form 1 & $-12.174^{*}$ & 2.873 & 0.00 \\
& Form 2 & 1.499 & 2.805 & 0.59 \\
Form 4 & Form 4 & -0.273 & 2.826 & 0.92 \\
& Form 1 & $-11.900^{*}$ & 2.8 & 0.00 \\
& Form 2 & 1.772 & 2.73 & 0.52 \\
& Form 3 & 0.273 & 2.826 & 0.92 \\
\hline
\end{tabular}

* The mean difference is significant at the 0.05 level.

\subsection{DISCUSSION CONCLUSIONS AND RECOMMENDATIONS}

\subsection{Discussion}

\subsubsection{Class level and Rebellion}

With regard to class level and adolescent rebellion, data analysis found no significant relationship. This implies that a student can be rebellious in any class not necessarily a specific level or form. There are those who can be rebellious in form one or two but as they progress to upper classes, they settle down, others may be settled in form one and two but as they get to form three or four, they become rebellious. This could be as a result of hormonal changes which either quickens the maturation process thus there are those who are early maturers who may become confident and less dependent and those who are late maturers who may become more rebellious as observed by Nancy (2001).Nancy and others are quiet on class level but focus more on the process. The recommended model educates parents and students on these aspects in order to empower them to be in control of themselves. 
Journal of Education and Practice

ISSN 2520-467X (Online)

Vol.1, Issue 1 No.1, pp 19-34, 2016

www.carijournals.org

\subsubsection{Class level and Parental Demandingness}

Analysis of data revealed that there was no significant relationship between class level and PD. This implies that parents can be demanding or not demanding irrespective of the class unlike the age. Studies carried out by Kinya (2007) and Munyua (2007) in primary and secondary school respectively revealed that class level did not significantly influence parenting styles. This could be the case because even the reviewed literature on this aspect does not directly address the class level but may be inferred indirectly through consideration of ages when one is expected to be in a certain form. This may be misleading bearing in mind that one can start his schooling late. Some parents may start being demanding in form one and two and as the student progress they decrease in their demands. Others may be very low in demandingness especially in academics but when grades deteriorate, they tighten their demands, for instance, in form three or four. The implication this findings have to teachers is to create awareness to parents to start getting concerned with their sons' behavior and academic performance early. This may impart more positive outcomes than if they start late.

\subsubsection{Class level and Academic Performance}

Data analysis on class level and academic performance found significant relationship between the two. Findings agree with those of teacher counsellor 4 who said that those who are caught by adolescence crisis in form two settle by the time they are in form 4 rather than those who get caught by the crisis in form 4 . Adolescence crisis in form 4 affect academic performance in that most of the student's energy is spent doing punishments other than reading; the mind is unsettled for academic tasks. When one get into crisis in form two, he has time to settle and recover unlike the one in form 4.

The current findings are closely related to those obtained by Gottfried, Fleming and Gottfried (2001) who found that on two aspects of continuity, stability of individual differences and means from middle elementary through the high school years among American adolescent, with age, academic intrinsic motivation becomes increasingly stable but the mean level of academic intrinsic motivation declines over the ages. Though Gottfried, Fleming and Gottfried (2001) measured the aspects of academic intrinsic motivation, it can be inferred that with increased stable academic motivation, there can be a tendency of performing well and vice versa. This can be done through educating parents on this aspect so that they contribute through firm control, encouragement and support verbal or otherwise to this important exercise.

\subsection{Conclusions}

Class level was found to have no significant relationship with PD and rebellion but it had a significant relationship with academic performance. As such there is need to increase academic intrinsic motivation in all classes to better academic performance through the proposed programme of educating and involving parents in this process.

\subsection{Recommendations}

The study recommends the following model for understanding the relationship between parental demandingness, -rebellion behaviour-academic performance, and demographic characteristics.

\section{Independent Variable}

\section{Dependent Variable}




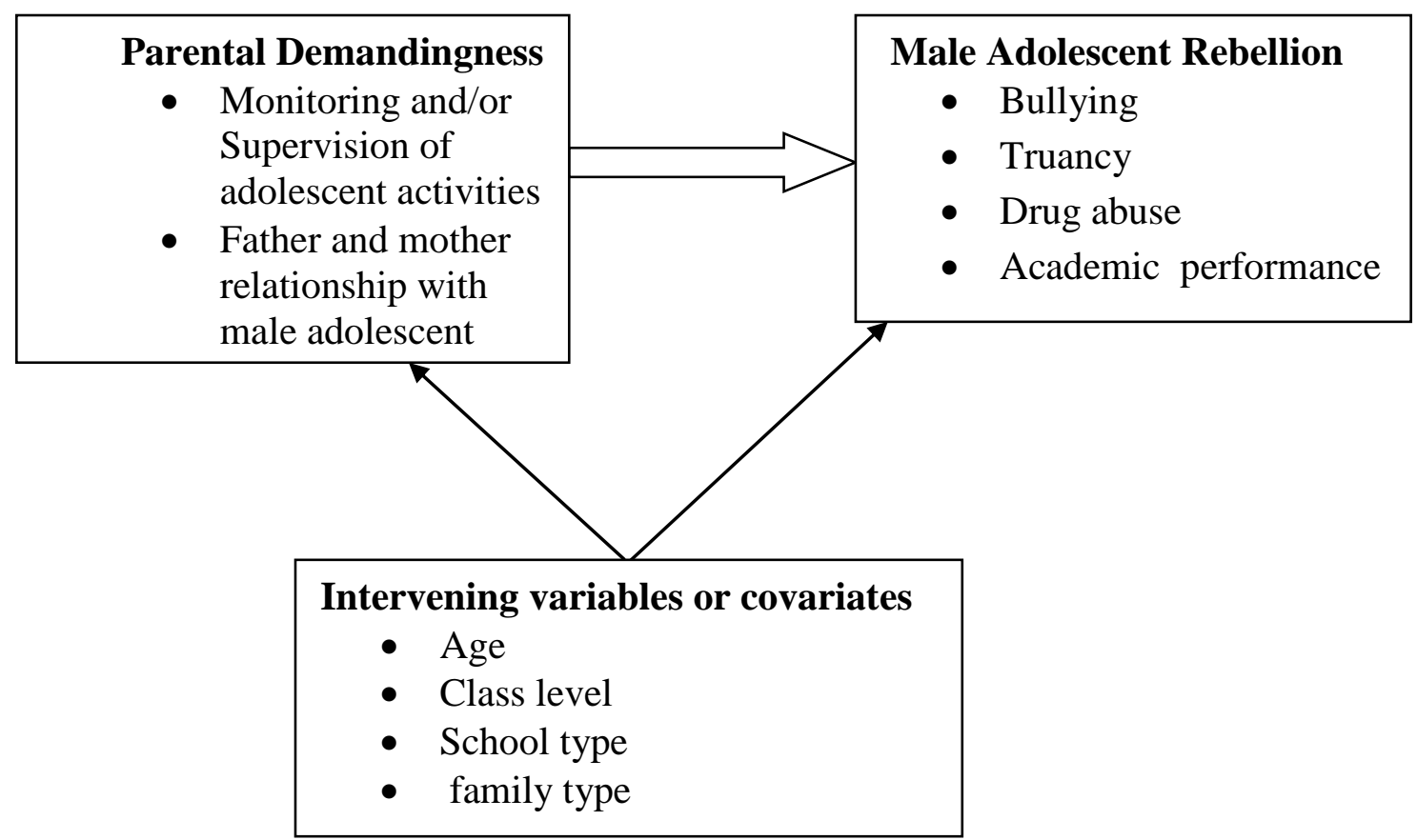

Figure 4: Original model highlighted in conceptual framework

\subsection{Areas for Further Studies}

Considering that the current study was one of its kind in investigating influence of PD dimension of parenting styles on rebellion among adolescent males in public secondary schools in Kiambu district, several recommendations arose from it.

Considering that the current study was carried out in a semi- urban area, it is then suggested that similar studies can be carried out in a purely urban area since students perception can be influenced by different environments.

A replica of this study can be carried out with a further scope to include girls in the study. The research may provoke further research in parenting style and investigating further the causes of adolescent rebellion.

A similar study can be done on girl's secondary schools and see whether the findings hold true.

This study should be advanced further to include other ingredients such as peer, technology, responsiveness that are key to academic performance in order to establish the degree to which each ingredient influences academic performance and also to establish whether other factors play a more influential role in the academic performance among Kenyan male secondary school students.

\section{REFERENCES}

Arnett, J. J. (2002). Emerging adulthood: A Theory-of Development From Late Teens Through Twenties. American Psychologist,55,469-480.

Astone, N. \& Maclanahan, E. L. (1991). Birth, Family Structure, Parental Practices and High School Completion. America Sociology Review, 56,309-320.

Babbie, E. R. (2004). The Basics of Social Research. Belmonte, CA: Thomson Wadsworth. Biu, T. (2011). Violence in Schools: Causes and Potential Solutions. Nairobi: Evangel. 
Journal of Education and Practice

ISSN 2520-467X (Online)

Vol.1, Issue 1 No.1, pp 19-34, 2016

www.carijournals.org

Bremner, P., Burnett, J., Nunney, F.,\& Mistal, W. (2011). Young People, Alcohol and Influences. A study of Young People and Their Relationship with Alcohol: NY: Joseph Rowntree Foundation.

Carole, A. \& Karen, K. (1997). Parenting: A Lifespan Perspective. NY: McGraw-Hill.

Dennis, C. (2004). Introduction to Psychology: Gateways to Mind and Behavior $\left(10^{\text {th }}\right.$ Ed.). Wadsworth: Thomson Learning.

George, T, Michael P. F. \& Grace, M. B. (1996). The effects of single- mother families and non-resident fathers on delinquency and substance use in black and white adolescents. Journal of Marriage and Family, Vol 58, 4, 884-889.

Gottfried, A., Fleming,J., \& Gottfried,A.W. (2001). Continuity of Academic Intrinsic Motivation from Childhood Through Late Adolescence: A Longitudinal Study. Journal of Educational Psychology, vol 93, 1, 3-13.

Harter, S. (1999). The Construction of The Self: A Developmental Perspective. NY: Guilford.

Jeffrey, J. (2004). Adolescence and Emerging Adulthood: A Cultural Approach. NJ: Prentice Hall.

Journal of Youth and Adolescent, vol 38, 9: 1240-1252.

Kariuki, N. S., Aloka, P. J., Kinai, T., Gatimu, N. H., Ndeke, F. N. (2014). Relationship between adolescent's perceptions of their parents' behaviors and youths' non illegal and minor- illegal delinquency in Nairobi secondary schools, Kenya. Journal of social science, Vol 5, 7.

Kelly, J. (2000). Children's adjustment in conflicted marriage and divorce: A Decade Review of Research. Journal of the American Academy of Child and Adolescent Psychiatry, 39, 963-973.

Kimathi, W. L. (2012). Influence of Drugs and Substance on Students Performance in KCSE in Igembe Meru. Unpublished Masters of Education Thesis, Kenyatta University.

Kinai, T. (2002). Relationship between Parental Behavior towards Adolescents and Their Manifest aggression. Kenyatta University, Unpublished Phd thesis.

Kinai, T. (2002). Relationship between Parental Behavior towards Adolescents and Their Manifest aggression. Kenyatta University, Unpublished Phd thesis.

Kinyua, C. W. (2007). Influence of Pupil's Perception of Parenting Styles on Their Academic Performance: A Case of Primary Schools in Eldoret Municipality. Moi University, Eldoret Unpublished M.phil thesis.

Latendresse, S. S., Rose, R. J., Viken, R. J., Pukkinen, L., Kapiro, J. \& Dick, D. M. (2008). Parenting Mechanisms in Links between Parents and Adolescents' Alcohol Use Behaviors. Alcoholism: Clinical and Experimental Research, vol 32, (2), 322-330.

Lester, M. (1993). Psychology $\left(2^{\text {nd }} E d\right)$. Iowa: Brown \& Benchmark.

Marcia, J. E. (1966). Development and Validation of Ego Identity Status among Different Groups in Kenya. Journal of Personality and Social Psychology, 3, 551-558.

Mugenda, O. M., \& Mugenda, A. G. (2003). Research Methods: Qualitative and Qualitative Approaches. Nairobi: Acts Press.

Munyua, J. K. (2007). Students' Perception of Discipline Practices and its Influence on Academic Performance Eldoret Municipality. Moi University, Unpublished M.phil Thesis.

Musuikuya, J. (2006, $26^{\text {th }}$ September). Indiscipline in Schools. Kenya Times, Nairobi, 6, Col $1-3$. 
Nancy, J. (2001). The Child: Infants, Children and Adolescents. California: Mayfield.

Narina, N., Debra, P. and Warren, A. (2007). The Story of Human Development. Upper Saddle NJ: Prentice Hall.

Ngare, P. (2000, 23 ${ }^{\text {rd }}$ February). "Hundreds Out of School in Central". East African Standard, Nairobi, pp 8, Col 4-5.

Ngwiri, L. N. \& Dinah, W. T. (2010). Challenging Parenting: What Every Parent of an Adolescent Should Know. Nairobi: Morning Dew.

Ngwiri, L.N. (2008). Powerful Parenting: What Every Parent Should Know. Nairobi: Printpack

Njenga, F. (2010). What is Wrong With this Child? Nairobi: Oxford University Press.

Okorodudu, G. N. (2010). Influence of Parenting Styles on Adolescent Delinquent in Delta Central Senatorial District. Delta State University, Unpublished MA thesis.

Onancha, E. (2007 $8^{\text {th }}$ July). "Bullying in Schools is Unacceptable". East African Standard, Nairobi, pp 6, Col 5.

Onyasimi, B. (2006, 20 ${ }^{\text {th }}$ May). "Let's Find Solution to Bullying in Schools". Kenya Times, Nairobi, pp 10, Col 2-4.

Osborne, C. \& McLanahan, S. (2007). Partnership Instability and Child Wellbeing. Journal of Marriage and Family, 69, 1065-1083.

Peleg-oren, N., Saint-Jean, G, Gardens, G. A., Tammara, H. \& Pierre, C. (2009). Drinking Alcohol Before Age 13 and Negative Outcomes in Late Adolescence 1, AlcoholismClinical and Experimental Research, 33, (11), 1966-1972.

Philip R. N. \& Barbara, M. N. (1986). Adolescent Development. Columbus: Merril Publishing Company.

Piaget, J. \& Inhelder, B. (1956). The Child's Conception of Space. London: Routledge \& Kegan Paul.

Ruth, S. (2009). The Effects of Age and Gender on Parental Control and Delinquency.

Sharon,R. G. \& Cheryl, B. (2010). Intrepersonal Conflict and Academic Achievement: An Examination of Mediating and Moderating Factors. Journal of Youth and Adolescence, vol39, 1, 23-25.

Stapley, J.C., \& Haviland, J. M. (1989).Beyond Depression: Gender Differences in Normal Adolescents' Emotional Experiences. Sex Roles, 20,295-308.

Steinberg, L. D., \& Silk, J. S. (2002). Parenting Adolescents. In Bronstein(Ed), Handbook of Parenting ( $2^{\text {nd }} E d$. vol (1). Mahwal, NJ: Erlbaum.

Wang, M. T., Dishion, T.., Stormhark, E. , \& Willett, J. (2011). Trajectories of Family Management Practices and Early Adolescent Behavioral Outcomes. Journal of Developmental Psychology, Vol, 47(5), pp, 1324-1341.

Wangui, B. (2008). Alarm Over High Boy School Dropout in Central. Standard, Nairobi, pp 21, Col 1-5.

Wesang'ula, M. John, O. \& Eric, K. (2011). Perceived Home Factors Contributing to Violent Behavior Among Public Secondary School Students in Western Province, Kenya. Journal of Emerging Trends in Educational Research and Policy Studies, vol 2(1), 30-40.

World Bank, (2002). Opening Doors: Education and the World Bank. Washington DC: World Bank. 